\title{
Self-Reliance as Panacea: Muddling Strategic Thinking in Australia
}

\author{
Robyn Lim and A. D. McLennan
}

$\mathrm{T}$

THE end of the Cold War has reduced strategic threat but increased strategic uncertainty: hence the difficulty of defining any 'new world order'. Security is not established in East Asia in the way it is in Western Europe; perilous conflict over the balance of power among China, Japan and the United States is possible, though not inevitable. No longer pinned down by the Soviet Union, China is a major beneficiary of the Cold War's outcome. Its strategic ambitions and willingness to use force in pursuit of its interests compound the problem of security in East Asia. So do the risk of nuclear proliferation on the Korean peninsula and the tensions between the two Korean states.

Australia, distant as it is from the sources of tension in East Asia, could choose to be passive in the face of strategic uncertainty, and concentrate solely on continental defence. Alternatively, it could choose to make a positive contribution, strategically and diplomatically, towards maintaining a benign balance of power in East Asia. The Labor government of 1983-96 tried to avoid this stark choice through a policy of conscious ambiguity encapsulated in the notion of 'self-reliance within a framework of alliances'. Emphasis on 'self-reliance' was prudent domestic politics because it played down the reality of defence dependence on the US; moreover, many on the left believed that a 'more independent' Australia would enjoy greater respect and so influence in its region. Meanwhile, reference to a 'framework of alliances' sustained the US alliance, so allowing the Labor government to enjoy the best of both worlds. But a policy of conscious ambiguity designed to meet the needs of different constituencies can be risky because it is open to varying interpretations by those who execute defence policy, and to controversy in public political argument, both giving rise to uncertainty that may diminish Australia's security.

'Self-reliance within the framework of alliance' represents a tenable basis for security policy only so long as Australians understand that it entails obligations and effort, that defence on the cheap is illusion, and that the alliance is an adjunct to national defence effort which functions on the basis of a congruence of interest. But the deliberate ambiguities of self-reliance have confused strategic thinking, and

Robyn Lim is Professor of Australian Studies at Hiroshima Shudo University and a former intelligence analyst at the Office of National Assessments. A. D. McLennan is an intelligence community consultant and a former official with experience in Foreign Affairs and the Office of National Assessments. 
produced strategic guidance that has resulted in questionable structuring for the Australian Defence Force (ADF).

\section{The Evolution of Self-Reliance}

The idea of defence self-reliance had been current since the $1920 \mathrm{~s}$, when it emerged in reaction against the appalling casualties of World War I and reflected the antagonism some felt towards Australia's defending remote imperial interests. The questioning of forward defence in the wake of the Vietnam war gave selfreliance official standing, which found expression in the Fraser Government's 1976 White Paper, Australian Defence (Killen, 1976). Noting that the European colonial powers had withdrawn from Southeast Asia and the US had disengaged from the Southeast Asian mainland, the White Paper concluded that Australia's area of prime strategic concern was its adjacent waters, the countries and territories of the Southwest Pacific, Papua New Guinea, Indonesia and the Southeast Asian region. Rather than basing its policy on the expectation of sending forces abroad to fight as part of some other nation's force, Australia would concentrate on defence selfreliance. Nevertheless, the 1976 White Paper did not rule out Australia's contributing to operations elsewhere if the requirement arose, provided that its presence was likely to be effective and forces could be spared from their 'national tasks'. But any such operations were more likely to be in Australia's neighbourhood than some forward or distant theatre (Horner, 1992:93).

The 1986 Dibb review, commissioned by Defence Minister Kim Beazley, refined the concept of self-reliance outlined in the 1976 White Paper. Dibb concluded that Australia was a defensible continent that, with some important reordering of priorities, could provide for its own defence (Dibb, 1986:17; see also Woodman, 1993:5-6). This conclusion reflected a desire to assert that Australia's defence was no longer hostage to the interests of 'great and powerful friends'.

The Dibb review's emphasis on continental defence caused concern in the US, where it was seen as outlining an Australian defence vision independent of the US that would weaken the global alliance structure on which US security depended and in which Australia played an important part. The review presented other difficulties. It gave priority to 'low-level contingencies' - pinprick raids in northern Australia (in fact the least likely threat) - but that pointed the finger at Indonesia. By thus suggesting an enemy, the Dibb review risked making one, on the basis of faulty logic dictated by political rather than military considerations.

The 1987 Defence White Paper — the Labor government's authoritative policy statement - modified Dibb's view by affirming that national policy was one of selfreliance within a framework of alliances. It allowed for possible Australian commitment of forces to situations distant from the immediate region: a policy flexibility to which Australia's force contribution to the 1991 Gulf War gave effect, if minimally.

Australia sent two frigates and a support ship to assist in the naval blockade of Iraq. 


\section{The US Alliance}

The US alliance is justified as contributing to Australia's 'self-reliant' defence posture by affording access to advanced military equipment and technology, training and exercising, intelligence and strategic dialogue, and by helping to preserve Australia's qualitative military advantage. The alliance also strengthens Australia's regional influence and security. Despite claims that Southeast Asians would prefer Australia to be 'more independent', Australia's security connections with the US reassure its regional friends.

If they are adaptable to changing strategic circumstances, alliances are a safeguard against uncertainty as well as threats, and contribute to both deterrence and defence by injecting considerable uncertainty into the calculations of potential aggressors. In event of war, the US alliance would add vastly to Australia's defence potential, as US support did for the United Kingdom during the Falklands war. Alliances also impose sensible restraint. Rash Australian behaviour would not attract IS support any more than Australia would support rash military action by (say) Papua New Guinea. Alliances do impose costs and risk, but not just on the smaller partner.

Grounded in mutual security interests, alliances entail expectations that need to be backed by deeds. Australia assisted in the Gulf War because Prime Minister Hawke and Delence Minister Bcazley appreciated that Australian interests were at stake. They also calculated shrewdly that, by committing forces at an early stage, Australia would avoid dangerous and risky opcrations. But shouting early while carrying a small stick may not work in the future if spending limitations and an emphasis on continental defence attenuate the ADF's force structure.

\section{Self-Reliance and Force Structure}

The defence Strategic Review 1.993 stated that major conflict should not determine Australia's force structure or preparedness (Department of Defence, 1993:43). And the following year's Whitc Paper Defending Australia said that 'the structure of the Defence Force is determined by its essential roles in providing for the defence of Australia' (Department of Defence, 1994:5). Moreover, the envisaged threats against which Australia should prepare were low-level and could arise with little warning.

As officially defined in Defending Australia, self-reliance required that 'we should be capable, without combat assistance from other countries, of defeating any attack which could credibly be mounted against $\Lambda$ ustralia' (Department of Defence, 1994:14). The ADF would do so on the basis of a self-reliant force structure developed to defend Australia from attack. Two consequences follow: Australia would not rely on allied combat forces for the defence of its territory; and the ADF's other roles would have no influence on decisions about force structure.

This policy seems prudent, so long as Australia's military means are sufficient to deter or defeat any threat it might face. But Australia has in fact been seeking delence on the cheap, and its defence spending is nowhere near the target envisaged 
in 1987 (Woodman, 1993:16). True, major acquisition programs have strengthened maritime power capabilities - desirably so. But the cost has been borne by the army, whose personncl strength is being wound back to the levels that preceded its assistance to Malaysia during its confrontation with Indonesia in 1963-66; and reliance on civil infrastructure tie the army's operations to defence of the Australian continent. These factors, by preventing the army projecting its forces beyond the continent, benefit any potential aggressor and reduce Australia's credibility as a contributor to alliance burden sharing.

\section{Regional Engagement}

The idea of regional engagement canvassed in the 1994 White Paper, while not exactly old wine in new bottles, represents a continuation of Australia's longestablished policy of fostering defence cooperation with Southeast Asian neighbours — no bad thing.

That Indonesia is top of the tree reflects its proximity and size, as well as its political and economic stabilisation under President Soeharto's New Order, and the moderation in its foreign policy. The 1995 Australia-Indonesia sccurity agreement sealed a relationship that had long been evolving. It promotes the interests of both countries by strengthening their mutual security and power. The agreement provides a basis for general cooperation, and affirms that their shared security interests outweigh their disagreements. It also identifies a shared interest in regional security that other states are obliged to take into account.

The agreement demands creative diplomacy and bold policy innovation. For Indonesia it is without precedent, while for Australia it is the first agreement concluded with a regional security partuer on the basis of reciprocal obligation. Although it docs not resolve all the extemal security problems of either side, it provides a strong foundation on which the Howard Government can build to Australia's advantage.

Australia also remains committed to the Five Power Defence $\Lambda$ rrangements as a building block of regional security. ${ }^{2}$ Singapore is the most direct beneficiary of defence coopcration with Australia. Its forces train, exercise and develop facilities in $\Lambda$ ustralia, supposedly to $\Lambda$ ustralia's financial gain. The agrecment with Singapore concedes far more in terms of Australian sovereignty than docs the US-Australia joint facilities agreement - a point umoted by its crilics.

But apart from the agreement with Indonesia, the Five Power Arrangements and practical measures of defence cooperation with the Philippines, 'regional engagement' remains a vague notion. It seems to have referred largely to the pursuit of mutual understanding - and so peace and security - through strategic dialogue, both bilateral and multilateral. The latter is conducted mainly through the ASEAN

\footnotetext{
${ }^{2}$ Members comprise Malaysia, Singapore, Australia, Britain and New Zealand. Britain's role is now vestigial. Five Power's most important element is an integrated air defence system for Malaysia and Singapore commanded by a senior RAAF officer. Five Power helped foster defence cooperation between Malaysia and Singapore in the aftermath of their separation.
} 
Regional Forum. Of Australia's prospective dialogue partners in East Asia, Japan is the most interesting and promising, with its instructively hardheaded approach to security.

Yet the idea of promoting regional security through cooperation and dialogue presents problems. Differences in values and interests can impede the development of relations with neighbours, as the East Timor issue shows with respect to Indonesia. The differences are partly cultural: Australia's plain-spoken diplomacy can jar Southeast Asian sensitivities. Human-rights considerations reflecting domestic imperatives have determined Australia's approach to Burma, whereas the ASEAN countries are concerned above all with the security consequences of Burma's international isolation.

More generally, the notion of regional engagement implies a congruence of security aims and interests among Southeast Asian countries that may not exist. It also presumes that these countries exercise more control over their security than their limited power permits. True, the Southeast Asian states are no longer, in the words of a former Indonesian foreign minister Adam Malik, a 'row of zeros' amounting to nothing. But even if they pooled resources, their combined power is less than that of the major states. Nor are they united in their security perceptions and interests. How many ASEAN countries, for example, would defend Vietnam if it came under military pressure from China, believing as they do that Vietnam's problems with China arc largely its own fault?

Another issuc is what Australia's regional engagement offers the countries so engaged. For geographical reasons, their defence efforts strengthen Australia's security. But if Australia structures its forces for continental defence, and seeks regional security through diplomacy without reference to strategic interests and ambitions, it will be offering little in return. That said, Australia's policy is not as naive as its diplomatic rhetoric sometimes sounds. Australia possesses military strength and related assets that would be useful in support of regional security; as well, it has as a growing defence industry and military technology base. And the Five Power Arrangements, bilateral defence cooperation programs and, above all, the strategic partnership with Indonesia are carnests of commitment.

\section{Strategic Connections between East and Southeast Asia}

Since the cnd of the Cold War, some in Australia have argued that the US will neglect security in Southeast Asia becausc its primary strategic interests lie in East Asia. That is to misunderstand the security conncctions between East Asia and Southeast Asia.

Some reduction in US military strength was both inevitable and desirable after the Cold War. In the new climate of reduced international tension, ISS public opinion refuses to countenance the role of world policeman; tolerance for American casualties in foreign wars is low. If they are to be politically sustainable, America's foreign commitments must be palpably comnected to America's direct security interests. It is still in the global strategic interest of the US that no hostile power or 
combination of powers should dominate Europe or East Asia. If Americans forget this basic lesson of 20th-century history, they are liable to rediscover it the hard way.

America's concern with maintaining a benign balance of power in East Asia (Japan, China, Korea and Russia) dates back at least to US President Theodore Roosevelt and his brokering of the settlement of the Russo-Japanese war through the Treaty of Portsmouth in 1905. It reflects the maritime basis of American security: as oceans are America's protection, events on the other side of them cannot be ignored. America's growing economic interests in East Asia reinforce these concerns.

A strategic interest in Southeast Asia and its waters is a necessary adjunct to American concern for the strategic balance that is evolving among China, Japan and the US. As ever, the security of the straits connecting the Indian and Pacific Oceans engages the strategic interests of the maritime powers and those who depend on their protection. With regard to China, Japan's maritime security represents a strategic interest of the first order for the US, given its responsibilities under the mutual security treaty with Japan, and the convenience for both parties of Japan's strategic dependence on US. This suits most countries in the region, though China is ambivalent.

The US-Philippines security treaty also directly involves the US in issues of strategic contention in the South China Sea. And the US possesses maritime and other military capabilities that give it influence possessed by no other distant state. China therefore has to take account of the American factor in pursuing its regional ambitions. This was starkly evident in relation to the US naval deployment in response to China's military intimidation of 'Taiwan before the latter's presidential election in March 1996.

China's claims in the South China Sea, which are suspended and revived at will, represent the most worrying challenge to strategic stability in the ASEAN area. China aims to divide the regional states, not least by seeking to settle differences with them bilaterally. The antagonism of Malaysia's Prime Minister Mahathir towards the West plays into China's hands, which doubtless worries the Indonesians. Mahathir's promotion of the East Asia Economic Caucus, which excludes the US, Australia and New Zealand, pits Asia's interests against those of the US and Europe, and so works to China's benefit. Thailand, for good reason, relies on China as a counter-weight to Vietnam. China also supports the friendless military regime in Burma in ways that arouse fears in India and the ASFAN countries of China's gaining a strategic foothold in the Indian Ocean.

The differences between the major actors that determine the East Asian balance of power and are manifest in Southeast $\Lambda$ sia do not stem from simple misunderstanding: they are grounded in strategic interest. Dialogue through a regional forum is not going to settle such differences. Only a stable power equilibrium can contain them.

Australia's alliances and defence activities afford it influence in Southeast Asia. Both connect with the strategic balance in East Asia. Membership of APEC may also help. Although APEC's remit does not cover security issues directly, it serves a 
broad strategic purpose by providing a framework in which all Asia-Pacific countries can tackle issues of common concern.

Japan's strategic dependence on the US is in Australia's interest. Without the US presence in Japan, China could feel even less constrained than it does now. And while Japan may lack strategic ambitions, it has strategic anxieties. Any breakdown of its alliance with the US would oblige Japan to look to its own security. Japan's relations with all its neighbours are uneasy. Surrounded by nuclear-armed states (perhaps including one day a united Korea), a strategically isolated Japan would be tempted to acquire both nuclear weapons and long-range maritime capability - whatever the strength of current Japanese pacifism. While some strategists regard with equanimity the prospect of a nuclear-armed Japan (see for example Waltz, 1981), its advent would provoke acute regional tensions.

\section{Australia's Nuclear Security}

Australia depends on its alliance with the US for nuclear security through extended deterrence. It pays its dues for this ultimate safeguard by hosting the defence joint facilities, visits from US navy ships, and the like. The other options available to Australia range from New Zealand's policy of eschewing nuclear weapons to the neo-Gaullist approach of former Prime Minister John Gorton and ex-Governor General Bill Hayden, which is grounded in scepticism about the reliability of nuclear-armed allies.

Sensible discussion about how nuclear weapons kept the peace in the Cold War and shaped the result is rare in Australia. Even rarer is sensible discussion about how they might (or might not) keep the peace in the future. That is partly because the logic of nuclear deterrence - the famous 'nuclear paradox' - is poorly understood. Fearing the destructive power of nuclear weapons, critics say (correctly in most cases) that they are umusable; but then conclude that they are useless. This conclusion is mistaken because nuclear weapons work all the time, deterring and containing, so long as the threat of their use is even slightly credible to governments or public opinion. But actual use of nuclear weapons on any substantial scale would void their utility because of the extent of destruction wrought or risked. Hence the paradox.

In order to appease anti-nuclear constituencies, the 1994 Defence White Paper said that Australia would continue to rely on US extended deterrence, but only as an interim measure until a total ban on nuclear weapons is achieved, accompanied by substantial verification provisions (p. 96). But such faith in diplomatic process is utopian. It ignores the fact that nothing could more weaken Australia's strategic security than the US dismantling its nuclear arsenal.

\footnotetext{
${ }^{3}$ Nuclear weapons also deter conventional attack — and unconventional, as in the 1991 Gulf War, when Iraq did not use its bacteriological and chemical weapons. Hence it does not follow, as is often assumed in Australia, that because Australia is not threatened with nuclear attack, it does not need nuclear protection.
} 
The Hawke Government's neutralising of the problems associated with the USAustralia joint facilities at Pine Gap, Nurrungar and Northwest Cape was immensely important in securing political support for Australia's reliance on extended deterrence. This aim was achieved by frank acknowledgment of the functions of the facilities, emphasis on their utility in monitoring arms control and disarmament agreements, and the assertion of Australian sovereignty.

Because the collapse of the Soviet Union has so reduced the strategic threat, much lower levels of nuclear armament are now appropriate. Prudent reduction of nuclear arms reinforces security. So would a reliable anti-proliferation regime. But these generalities offer no helpful guidance on the optimum level of residual nuclear armament. And there is a risk, with the Cold War ended, that nuclear deterrence will be viewed as irrelevant to Australia's security or as involving unacceptable dangers. But nuclear weapons are too useful to disappear. Their technology is known and camnot be unlearned. The Western nuclear powers will continue to depend on nuclear weapons because they could not endure the mass casualties of general war. Their defence must therefore rely on preserving a technological edge and the ability to inflict intolerable damage on a populous enemy. It is an apposite truism that abolishing nuclear weapons would make the world safe for conventional war, and so work to the strategic advantage of totalitarian states with large, expendable populations.

China sees nuclear weapons as the key to the level of security and influence that it desires. As it continues developing its nuclear arsenal, it is very likely seeking a secure, submarine-based force. An aim of France's last round of nuclear testing was to increase the security and effectiveness of its own submarine-based force. Recent Russian talk suggests that it recognises that nuclear weapons now constitute its main claim to global influence.

\section{The Risks of Self-Reliance}

'Self-reliance' and 'defence of Australia' have muddled our strategic thinking. 'Selfreliance' critically blurs the distinction between defence and security. 'Defence' focuses on the threat of invasion, while 'security' is a broader concept encompassing freedom from constraint by threats, intimidation or other pressures, from whatever source, that would unacceptably limit national policy choices. For Australia, such constraints may be as geographically distant as, for example, Germany's pursuit of hegemony over Europe or the Soviet Union's over Eurasia.

History's lesson for Australia, because of its remoteness from the centres of international tension and its surrounding seas, is that major strategic threats may develop as a result of distant disruption of the balance of power, as occurred in both World Wars and during the Cold War. Australia could have sought to avoid the consequences of such threats by averting its gaze and not fighting 'other people's

\footnotetext{
For example, Japan struck southwards in 1941, calculating that Germany would defeat the Soviet Union and the Western allies. A breakdown of the balance of power distant from Australia resulted in attacks on Australia's territory.
} 
wars'. Instead, it chose, responsibly, to intervene. By adding its weight to the efforts of the compatible side it helped ensure a favorable outcome; and by taking the fight to the enemy, Australia reduced the risk of war on its own territory. This policy recognised that Australia would find life very difficult in an international order dominated by hostile powers, even if Australia itself were not invaded. Such would have been the case in 1942 had Japan been able to isolate Australia from the US.

Emphasising self-reliance, narrowly defined, encourages thinking in concentric circles: the idea that threats diminish and vanish with distance. Such logic informed New Zealand's rejection of visits by nuclear-armed US ships, part of a strategy whereby that country effectively sought to retain the benefits of extended deterrence conferred by the ANZUS treaty while avoiding its treaty obligations. Analogous for Australia would be a security doctrine that took account only of direct threats to its territory. But Australia needs to worry about threats to its security and independence wherever they arise. Iraq's invasion of Kuwait was a case in point because of the challenge that it posed to broad international security.

Democracies find it hard to think strategically when their security seems not to be threatened. Australia is a typical, naturally secure country with little instinctive understanding of how strategic interests, military power and threat of force shape the conduct of international relations. This failing reflects the human belief that unpalatable problems will go away if ignored, are better not discussed or are amenable to procedural solutions that ignore interests.

But the principles of security are enduring. Australia's interests after the Cold War remain as they were before: in seeing disputes resolved and a satisfactory power equilibrium struck at a distance, not on its shores. The balance of power in East Asia is the critical factor shaping Australia's strategic security. The consequences of a breakdown of that balance are unlikely to manifest themselves as lowlevel attacks at short warning on Australia's territory. But they are likely to emerge in Southeast Asia. Alliances and 'regional engagement' based on appreciation of interests strengthen Australia's hand, and so encourage the evolution of a benign balance in East Asia.

\section{References}

Department of Defence (1993), Strategic Review, 1993, AGPS, Canbera.

(1994), Defending Australia, AGPS, Camberra.

Dibb, P. (1986), Review of Australia's Defence Capabilitics, Report to the Minister for Defence, AGPS, Canberra.

Honter, D. (1992), 'The Security Dimensions of Australian Foreign Policy', in F. Mediansky (ed.), Australia in a Changing World, Maxwell Macmillan, Sydney.

Killen, D. (Minister for Defence) (1976), Australian Defence, AGPS, Canberra.

Walt, K. (1981), 'The Spread of Nuclear Weapons: More May Be Better', Adelpli Papers 171: passim.

Woodman, S. (1993), Australian Security Planning at the Crossroads: The Challenge of the Nineties, Strategic and Defence Studies Centre, Australian National University, Canberra (Working Paper No. 271). 